\title{
Trifecta of Engagement in an Online Engineering Management Course
}

\section{Dr. Peilin Fu, National University}

Peilin Fu, Ph.D., received the Master of Engineering in Electrical Engineering from Ocean University of China, China, and Ph.D. in Systems Engineering and Engineering Management from the Chinese University of Hong Kong, Hong Kong. She is currently a Professor with the Department of Applied Engineering, School of Engineering and Computing, National University, San Diego, California, USA. She was formerly a Lecturer in the Department of Electrical Engineering, University of California, Riverside during 2004-2008, and a Research Associate in the Department of Electrical and Electronic Engineering, Hong Kong University of Science and Technology during 2003-2004. Dr. Fu is an Associate Editor of the Journal of Control Science and Engineering, and has been served as the International Program Committee Member and Organizer of several international conferences and workshops. 


\title{
Trifecta of Engagement in an Online Engineering Management Course
}

\begin{abstract}
This paper focuses on how to engage students in an online environment. The Trifecta of Engagement framework is introduced. In order for students to be fully engaged in a course, they need to be engaged with (1) their course content, (2) their peers, and (3) their instructor. The author shares the experiences in teaching an online Engineering Management Course in this paper. The student-to-content engagement, student-to-student engagement, and student-toinstructor engagement are highly strengthened through a series of well-designed course activities. The end of course student assessment shows that students demonstrated an apparent increase in engagement and enthusiasm toward the subject matter. Although lacks of the face-toface communication, the online course with Trifecta of Engagement framework applied prevails over the same course taught onsite in all of the assessment questions.
\end{abstract}

\section{Introduction}

Student engagement refers to the degree of attention, curiosity, interest, optimism, and passion that students show when they are learning or being taught, which extends to the level of motivation they have to learn and progress in their education. Generally speaking, the concept of student engagement is predicated on the belief that learning improves when students are inquisitive, interested, or inspired, and that learning tends to suffer when students are bored, dispassionate, disaffected, or otherwise "disengaged" [9].

Student engagement has enjoyed considerable attention in the literature since the mid-1990s. Fredricks, Blumenfeld and Paris [10], identify three dimensions to student engagement:

- Behavioral engagement: Students who are behaviorally engaged would typically comply with behavioral norms, such as attendance and involvement, and would demonstrate the absence of disruptive or negative behavior.

- Emotional engagement: Students who engage emotionally would experience affective reactions such as interest, enjoyment, or a sense of belonging.

- Cognitive engagement: Cognitively engaged students would be invested in their learning, would seek to go beyond the requirements, and would relish challenge.

Coates [11] describes engagement as "a broad construct intended to encompass salient academic as well as certain non-academic aspects of the student experience”, comprising the following:

- active and collaborative learning; 
- participation in challenging academic activities;

- formative communication with academic staff;

- involvement in enriching educational experiences;

- feeling legitimated and supported by university learning communities.

These five facets form the basis of the National Survey of Student Engagement (NSSE), the annual survey conducted among public and private higher education institutions in the US and Canada.

One of the main challenges both faculty and students encounter in online courses, unlike many face to face courses, is a general feeling of isolation. Online students are physically separated. This can result in a decrease of opportunities for academic and social integration which are known predictors of student success for those who take traditional classes. Likewise, instructors who teach online may find that they lose out on the relational awards associated with teaching to a live audience because they are distanced by space and time. There are three essential areas online students need to be engaged in if they are going to be successful. Students need to be engaged with their course content, with their peers and with their instructor. When students are engaged in all three areas it is known as the Trifecta of Engagement as shown in Figure 1.

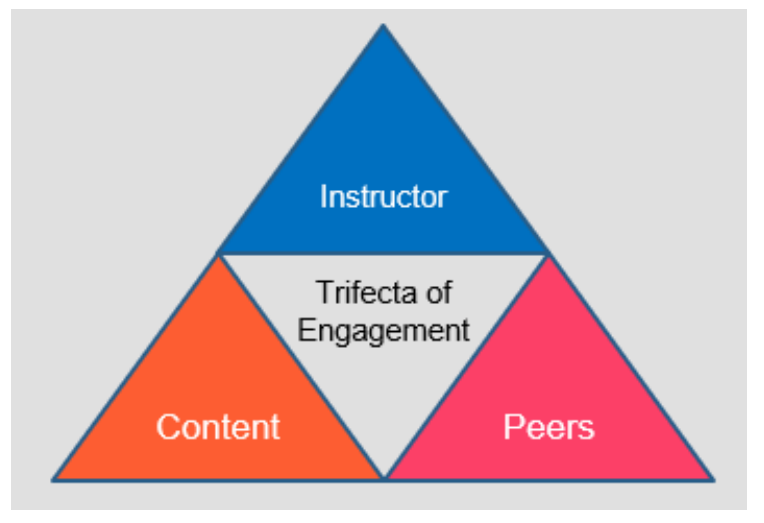

Figure 1: Trifecta of Engagement

When students are fully engaged in a course in this way the benefits are endless. They will get so much more out of their course. Their chances of persisting and graduating increase. And their satisfaction will increase. Likewise, instructor satisfaction will also increase and it will be a better learning experience for all.

This paper introduces the framework of Trifecta of Engagement. The author shares the experiences in designing and teaching an online Operations Management Course. Through welldesigned class activities such as online sessions, instructional videos, assignments, threaded discussions, journals and group projects etc., student-to-content, student-to student, and studentto-instructor engagement have been greatly improved. The students' feedback and the end-ofcourse survey were collected at the end of the course, which demonstrated that these teaching 
methodologies stimulated students' curiosity and critical thinking, improved students' problemsolving skills, thus ensured that students were better prepared for future engineering practice.

\section{Operations Management Course}

Operations management refers to the systematic design, direction, and control of processes that transform inputs into services and product for internal, as well as external customers. It is a vital topic that every engineering management student needs to understand because it is at the heart of the creation of wealth for business and the improvement in the living standard of citizens of all countries [1]. Operations Management has been listed as a core course in the management science and engineering programs all around the world [3]. This course usually covers broad areas such as process analysis, quality and performance, capacity planning, supply chain, inventory management, forecasting, operations planning and scheduling, and resource planning etc., which are all closely related with the daily operations of enterprises. However, due to lack of experiences in business operations, most of the students feel the course difficult to learn. The traditional teacher-oriented teaching method, in which the teacher explains the textbook contents to students, makes students lose interests and confidence. An online Operations Management course in which the students and instructor have limited/no face-to-face communications is even more challenging.

How to stimulate students' enthusiasm and critical thinking, and increase students' engagement in and out of classroom is crucial for effective teaching of this subject, thus should be highly valued. The initial purely theory-oriented mode has been gradually adjusted to active learning (getting students to do things in class that actively engage them with the material being taught), cooperative learning (putting students to work in teams under conditions that promote the development of teamwork skills while assuring individual accountability for the entire assignment), and problem/task-based learning (teaching material only after a need to know it has been established in the context of a complex question or problem, which increases the likelihood that the students will absorb and retain it) [7], thereby improving students' learning initiative to a certain extent [2], [3].

\section{Accelerated Course Format}

Founded in 1971, National University is the second-largest private, nonprofit institution of higher education in the state of California. For more than forty years, it has been dedicated to making lifelong learning opportunities accessible, challenging, and relevant to a diverse student population. National University provides challenging and relevant programs that are studentcentered, success-oriented, and have a proven balance of theoretical and practical attributes. A leader in online education, National University offers more than 70 graduate and undergraduate degree programs and over 1,200 courses online. These programs and courses are delivered using the up to date technology to provide dynamic, interactive learning environments, online, 24 
hours a day, seven days a week. The unique one-course-per-month format (students only take one course each month and complete it in four weeks) gives students unprecedented focus and flexibility, and lets the students earn their degree on their own schedule. But on the other hand, this accelerated course format, where the students need to complete one course in four weeks, make the courses especially challenging to students.

Under the one-course-per-month framework, the Operations Management course contents were divided into four major topics, each for one week as shown in Table 1. Each week's lesson will consist of reading from the text, online Blackboard Collaborate sessions, question and answer via discussion board, homework assignments, quizzes/exam and a group project.

Table 1: Course Topics and Class Activities

\begin{tabular}{|c|l|l|}
\hline Date & \multicolumn{1}{|c|}{ Topics } & \multicolumn{1}{c|}{ Class Activities } \\
\hline Week 1 & Planning Operations: & - Assignment \#1 \\
& - Using Operations to Compete & - Threaded discussions \\
& - Decision Making & - Online BB Collaborate session \\
& - Forecasting & - Quiz \#1 \\
& & - Group project idea \\
& & - Journal \\
\hline Week 2 & Operations Design and Analysis: & - Assignment \#2 \\
& - Process Strategy & - Threaded Discussions \\
& - Process Analysis & - Online BB Collaborate session \\
& - Supply Chain Integration & - Quiz \#2 \\
& & - Development of project \\
& & -Journal \\
\hline Week 3 & Optimizing Operations: & - Assignment \#3 \\
& - Quality and performance & - Threaded discussions \\
& - Capacity Planning & - Online BB Collaborate session \\
& - Waiting Lines & - Quiz \#3 \\
& - Operations Planning and & - Project report draft \\
& Scheduling & - Journal \\
\hline Week 4 & Manufacturing Operations: & - Assignment \#4 \\
& - Supply Chain Inventory & - Threaded discussions \\
& Management & - Online BB Collaborate session \\
& - Recourse Planning & - Final exam \\
& - Lean Systems & - Final project report \\
& & - Journal \\
\hline
\end{tabular}

\section{Student-to-Content Engagement}

Student-to-Content Engagement is the first component of the Trifecta of Engagement. Simply providing academic content materials for students to passively absorb will not effectively cultivate learning. Rather, providing students with opportunities to do something with the course content such as solve problems, ask questions, examine concepts, compare and contrast views, 
and complete challenges and exercises allows engagement to occur [12]. Activities that go beyond passively taking in information to making meaning of that information follow a constructivist approach to learning also referred to as 'active learning'. This approach tends to work well for adult learners who bring life experience to draw on to make meaning of new information [13, [14].

There are many strategies that can make the learning environment and course contents appealing and encourage Students-to-Content engagement . The key idea is through class activities to give students the opportunity to make meaning of the content. The following are two class activities I used in my ENM603 course to foster Student-to-Content engagement.

\section{- Instructional Video}

Research shows that people can only remember $10 \%$ of what they read, and $20 \%$ of what they see and hear. Video has the ability to convey material through auditory and visual channels, creating a multisensory environment. Choi and Johnson [15] found that the use of instructional videos can motivate learners by attracting their attention and can help with comprehension and retention of information through the use of visual and audio aids. In online courses, instructional videos can serve as a significant component to present content as video can be engaging for learners.

In ENM603, instructional videos were used to demonstrate a procedure, explain a detailed method, or bring a process or idea to life using 3-D images, audio, and graphics. Every weekly unit, there are two to six videos embedded in the course website serving as supplements to reading assignments. Besides instructional videos, videos from professional societies and conference keynote speech broadened students' horizons and exposed them to real-world problems.

\section{- Simulation}

Computer simulations have become increasingly powerful and available to teachers in the past three decades. The computer simulations can facilitate teaching and learning through visualization and interaction with dynamic models of natural phenomena. Since the computer simulations show simplified versions of the natural world, they can focus students' attention more directly on the desired phenomenon. Additionally, computer simulations may allow students to visualize objects and processes that are normally beyond the user' control in the natural world. In comparison with textbooks and lectures, a learning environment with a computer simulation has the advantages that students can systematically explore hypothetical situations, interact with a simplified version of a process or system, change the time-scale of events, and practice tasks and solve problems in a realistic environment without stress [16]. 
OM Explorer and Microsoft Excel were used in ENM603 for student to approximately imitate the operation of a real process or system. Students used these software to do break-even analysis, make decisions, forecast sales, create control charts, and imitate waiting lines etc. As most students haven't got a chance to access real operation processes/systems, these simulation practices and hands-on activities not only engaged them in real world problems, but also stimulated critical thinking and developed skills of questioning and reasoning.

\section{Student-to-Student Engagement}

Humans are social beings and this affects how we learn. Social learning theory, developed by Albert Bandura [17], suggests that people learn from one another via observation, imitation, and modeling. Socialization online has become a driving force in people's lives, particularly with the rise of social media and social networking. Collaborative and cooperative learning are popular instructional strategies in online teaching with students working together to solve problems, complete projects, and learn from one another through discourse [18]. Linda Harasim's [19] online collaborative theory provides a framework for how learners construct knowledge in an online community in which ideas are generated, organized, compared, analyzed, and categorized through discussion and argument. Learners eventually reach 'intellectual convergence' where consensus is reached, including agreeing to disagree, usually through a group deliverable such as a project, although the learning never really ends. This is referred to as 'project-based learning' where students are presented with a problem to solve or question to answer and work on this collaborative project for an extended period of time [18]. Student-to-student engagement activities in an online course can include collaborative tools such as discussion boards, group projects, wikis, blogs, journals and peer assessments etc.

\section{- Threaded Discussions}

The online threaded discussion provides students an opportunity to participate in virtual conversations at any time and any location. It can help students synthesize knowledge into understanding of the weekly course learning objectives. Evidence showed threaded discussions increased the amount of time students spent on class objectives comparing to face-to-face discussion as in an onsite class. And the students appreciated the extra time for reflection on course issues [4]. It was also reported that online threaded discussion can improve critical thinking [5]. A study at Athabasca University [6] found online students "experienced greater cognitive and explanatory learning” as a result of greater participation in course communications where students exchanged "between 80 and 100 messages, which is far richer than the classroom.”

In the Operations Management course, each week several real-world open-ended questions, shown as below, were assigned in the Discussion Board for students to answer. 
o Consider Amazon.com, whose web site enjoys millions of "hits" each day and puts customers in touch with millions of services and products. What are Amazon's competitive priorities and what should its operations strategy focus on?

o What do you think is a good service package of a grocery store like Von's, Albertson's, or Ralph's? What do you think are some of the issues in adding a new service, like home delivery, to their service package?

o How do the process strategies of eBay and McDonald's differ, and how do their choices relate to customer-introduced variability?

o Firms such as Wal-Mart, General Electric, Chase Manhattan, and Boeing have a lot of influence in their respective supply chains because of the power they have. Explain how firms with a lot of power can influence supply chain integration.

o Hospitals and manufacturing companies both are concerned with quality and utilize TQM programs. Discuss the similarities and differences between these organizations and how they provide quality and utilize TQM.

o Some employers maintain stable workforces at all costs, while others layoff and recall workers seemingly at the drop of a hat. Discuss what you think are the differences in markets, management, products, financial position, skills, costs, and competition that could explain these two extreme personnel policies.

Students need to respond to these instructor's questions and other students' postings. Students were asked to be creative, and synthesize, enlighten, inspire and add insight to the discussion. Instead of a discussion being limited to the time set aside for the face-to-face class, these online threaded discussions occurred over a week. "It takes a lot of time" was not an uncommon comment from students. Almost every student spent substantial time to read others' postings, think about a response, prepare a response, and check back later to see others' contributions to the discussion. Exploring these questions, students identified what they already knew, what they needed to know, and how and where to access new information that may lead to the resolution of these problems.

\section{- Group Project}

In order to bridge the gap between the knowledge the students learned from the textbook and the business operations experiences, I designed a group project for students to complete. Each student group need to apply knowledge from the course to solve a real world problem and turn in a project report by the end of the course.

The primary emphasis of the group project is to define the real-world problem and then discuss how it might be solved. The problem definition needs to

o Provide background of the situation

- What has been happening

- What are some symptoms or how has this problem come to your attention 
o Provide a statement of the problem gap

- Current situation or status

- Desired situation, or goal state

o Provide evidence and data about the current situation

o Be clear about how the achievement of the goal will be determined

The project should also discuss the following steps based on knowledge from Engineering Management:

o You should recommend how you will generate solutions and evaluate them

o How you will plan and implement the solution

o How you will follow-up and make corrective action

o Make recommendations for how they will be done.

The project report needs to include at least three academic references from academic journals or books in addition to magazine articles, websites, newspaper articles, etc. The report needs to be thorough and complete to convey students' point and limited to a max of 10 type written pages, 1 $1 / 2$ line spacing. The format of the report needs to follow APA format.

There were nine students in total enrolled in ENM603 in October, 2018. The students were divided into five project groups according to their preference. Each group has at most two students. Each group of students selected the topic of their choice upon consultation with the instructor in the first week. The student groups were provided File Exchange, Discussion Board, Email and Group Journal Tools to better communicate and interact with their team member.

\section{- Journal Assignment}

Journal assignment is a great tool to enhance the development of critical thinking, and increase students' engagement with their team member and the instructor. The following journal assignment was created for each group of students to post opinions, ideas, and concerns about their project, or discuss and analyze project related materials between instructor and students.

"Each week you will be writing an journal entry/entries regarding your group project. This is a private space where you can share resources with your partner, discuss project related issues, record project progress and get personalized feedback from your instructor.

Please make sure that your journal includes the following information:

1. The progress achieved in your project during this week.

2. The difficulties you encountered during this week. And how did you solve the problems?

3. Useful published resources that you would like to share with your partner.

4. Please feel free to add any other comments or questions you wish to ask your Instructor."

\section{Student-to-Instructor Engagement}


Online learning presents new challenges when compared to a traditional classroom because students are separated from their instructor by a computer screen. The instructor needs to provide multiple ways of interacting with students to create their own social presence, which the literature confirms is an integral component to a successful online course [20], [21]. Several channels were used in ENM603: announcements on course website, e-mails to students, discussion forums, virtual office, and online lecture sessions etc., to enhance student-to-instructor engagement. In addition, rubrics were used to communicate student progress and evaluate student's performance in journal assignment, threaded discussions and project report.

\section{- Blackboard Collaborate Sessions}

The Blackboard Collaborate session is a great tool to create a student-centered learning environment online. Students and instructor can engage and interact as if there were in a traditional classroom with two-way audio, interactive whiteboard, application and desktop sharing , session recording etc. In the Operations Management course, two Blackboard Collaborate Sessions were scheduled every week, each for two hours. Unlike traditional lectures, in which the instructor is the only one who is active and students are just watching , listening and taking notes [7], the students were asked to work individual or in groups on brainstorming, problems solving and case studies. At the end of the allotted time, the instructor called on individuals or teams for their responses and/or solutions. The goals of these sessions were to help students develop flexible knowledge, effective problem solving skills, self-directed learning, effective collaboration skills and intrinsic motivation. The role of the instructor was to facilitate learning by supporting, guiding, and monitoring the learning process. The sessions were recorded which gives flexibility to students who could not attend an online session. If the student had to miss an online session, he/she could review the recorded session and submit a 1-2 page summary to the instructor to get credit for the session.

\section{- Rubrics}

Scoring rubrics were used in ENM603 to communicate the expectations, provide feedback, and evaluate the quality of journal assignment and project report. They were also used to delineate consistent criteria for grading.

The journal assignment was evaluated using three criteria: reflection, clarity and grammar. The levels of achievement (novice, competent and proficient) were defined as shown in Figure 2. 


\begin{tabular}{|c|c|c|c|}
\hline \multirow[b]{2}{*}{ Criteria } & \multicolumn{3}{|l|}{ Levels of Achievement } \\
\hline & Novice & Competent & Proficient \\
\hline Reflection & $\begin{array}{l}8 \text { Points } \\
\text { Journal entries list the actions of } \\
\text { the student but often fail to } \\
\text { illustrate the logical and critical } \\
\text { thinking processes of the } \\
\text { researcher. }\end{array}$ & $\begin{array}{l}12 \text { Points } \\
\text { Journal entries document the personal } \\
\text { insights, successes, and reflections of } \\
\text { the student. Some evidence of logical } \\
\text { and critical thinking is shown. }\end{array}$ & $\begin{array}{l}16 \text { Points } \\
\text { Journal entries document the personal } \\
\text { insights, successes, and reflections of the } \\
\text { student. Clear evidence of logical and } \\
\text { critical thinking process is shown. }\end{array}$ \\
\hline Clarity $\odot$ & $\begin{array}{l}4 \text { Points } \\
\text { Entries are not easily read and } \\
\text { understood. }\end{array}$ & $\begin{array}{l}8 \text { Points } \\
\text { Entries are easily read and understood } \\
\text { but often lack an identifiable point. }\end{array}$ & $\begin{array}{l}12 \text { Points } \\
\text { Entries are easily read and understood. } \\
\text { An evident purpose for each entry can be } \\
\text { identified. }\end{array}$ \\
\hline Grammar & $\begin{array}{l}4 \text { Points } \\
\text { There are excessive amount of } \\
\text { grammar, punctuation, and } \\
\text { spelling errors that make the } \\
\text { writing difficult to understand. }\end{array}$ & $\begin{array}{l}8 \text { Points } \\
\text { There are some grammar, punctuation, } \\
\text { and spelling errors that somewhat } \\
\text { interfere with the reader's } \\
\text { understanding of the writing. }\end{array}$ & $\begin{array}{l}12 \text { Points } \\
\text { There are no grammar, punctuation, and } \\
\text { spelling errors in the journal. }\end{array}$ \\
\hline
\end{tabular}

Figure 2: Grading Rubric for Journal Assignment

The evaluation of the project report was based on five criteria: facts, analysis, research, vocabulary and grammar, and form as shown in Figure 3. The levels of students' achievement were defined as poor, fair, good, and outstanding.

\begin{tabular}{|c|c|c|c|c|}
\hline \multirow[b]{2}{*}{ Criteria } & \multicolumn{4}{|l|}{ Levels of Achievement } \\
\hline & Outstanding & Good & Fair & Poor \\
\hline Facts ( & $\begin{array}{l}19 \text { to } 25 \text { points } \\
\text { The student provided } \\
\text { expert information relevant } \\
\text { to the topic. The detail and } \\
\text { scope of the information } \\
\text { incorporated into the } \\
\text { project demonstrates } \\
\text { exceptional familiarity with } \\
\text { the topic. }\end{array}$ & $\begin{array}{l}13 \text { to } 18 \text { points } \\
\text { The student provided accurate } \\
\text { information relevant to the } \\
\text { topic. The student could have } \\
\text { provided greater detail and } \\
\text { scope. The detail and scope of } \\
\text { the information incorporated } \\
\text { into the project demonstrates } \\
\text { considerable familiarity with } \\
\text { the topic. }\end{array}$ & $\begin{array}{l}7 \text { to } 12 \text { points } \\
\text { The student had some } \\
\text { difficulty furnishing } \\
\text { sufficient evidence. } \\
\text { The detail and scope } \\
\text { of the information } \\
\text { incorporated into the } \\
\text { project demonstrates } \\
\text { limited familiarity with } \\
\text { the topic. }\end{array}$ & $\begin{array}{l}0 \text { to } 6 \text { points } \\
\text { The student failed to } \\
\text { provide information that is } \\
\text { accurate and relevant to } \\
\text { the project. The detail and } \\
\text { scope of the information } \\
\text { incorporated into the } \\
\text { project was insufficient. }\end{array}$ \\
\hline Analysis & $\begin{array}{l}19 \text { to } 25 \text { points } \\
\text { The student analyzed the } \\
\text { question / problem / thesis } \\
\text { from all relevant } \\
\text { perspectives. Facts, key } \\
\text { concepts and principles } \\
\text { were presented in an } \\
\text { orderly fashion. Inferences } \\
\text { were logically sound and } \\
\text { conclusions were wel } \\
\text { supported. }\end{array}$ & $\begin{array}{l}13 \text { to } 18 \text { points } \\
\text { The student analyzed the } \\
\text { question / problem / thesis } \\
\text { from multiple perspectives. } \\
\text { The student's presentation of } \\
\text { facts, and principles was } \\
\text { orderly; with one erroneous } \\
\text { inference. }\end{array}$ & $\begin{array}{l}7 \text { to } 12 \text { points } \\
\text { The student analysis of } \\
\text { the question / problem } \\
\text { / thesis was limited. } \\
\text { Some of the facts, are } \\
\text { presented in a } \\
\text { disorderly fashion with } \\
\text { some erroneous } \\
\text { inferences. }\end{array}$ & $\begin{array}{l}0 \text { to } 6 \text { points } \\
\text { The student failed to } \\
\text { analyze the question ! } \\
\text { problem / thesis. } \\
\text { Presentation of facts, key } \\
\text { concepts and principles is } \\
\text { disorderly and there are } \\
\text { multiple errors in } \\
\text { reasoning. }\end{array}$ \\
\hline
\end{tabular}




\begin{tabular}{|c|c|c|c|c|}
\hline Research & $\begin{array}{l}16 \text { to } 20 \text { points } \\
\text { The student has used a } \\
\text { wide variety of informative } \\
\text { and relevant appropriate } \\
\text { professional sources, and } \\
\text { integrated them seamlessly } \\
\text { into the body of the project. } \\
\text { Conclusions are verified or } \\
\text { verifiability has been } \\
\text { incorporated. }\end{array}$ & $\begin{array}{l}\mathbf{1 1} \text { to } 15 \text { points } \\
\text { The student has used a } \\
\text { sufficient number of } \\
\text { informative and relevant } \\
\text { appropriate primary } \\
\text { professional sources. } \\
\text { Conclusions are logical. }\end{array}$ & $\begin{array}{l}6 \text { to } 10 \text { points } \\
\text { The student has } \\
\text { provided sources but } \\
\text { had difficulty } \\
\text { integrating them. } \\
\text { Conclusions are } \\
\text { incomplete, } \\
\text { questionable, or } \\
\text { difficult to discern. }\end{array}$ & $\begin{array}{l}0 \text { to } 5 \text { points } \\
\text { The student has failed to } \\
\text { provide sufficient relevant } \\
\text { sources for this } \\
\text { assignment and/or failed } \\
\text { to adequately incorporate } \\
\text { outside sources into the } \\
\text { body of the project. } \\
\text { Conclusions are missing, } \\
\text { irrelevant or unacceptable. }\end{array}$ \\
\hline $\begin{array}{l}\text { Vocabulary } \\
\text { and } \\
\text { Grammar }\end{array}$ & $\begin{array}{l}16 \text { to } 20 \text { points } \\
\text { The student has combined } \\
\text { the effective use of subject- } \\
\text { specific terminology with } \\
\text { extensive vocabulary and } \\
\text { variety of expression. The } \\
\text { student consistently uses } \\
\text { correct grammar, syntax, } \\
\text { spelling, punctuation, and } \\
\text { capitalization. }\end{array}$ & $\begin{array}{l}11 \text { to } 15 \text { points } \\
\text { The student has demonstrated } \\
\text { good use of vocabulary and } \\
\text { variety of expression The } \\
\text { student has an average of } \\
\text { fewer than } 3 \text { errors per page in } \\
\text { grammar, syntax, spelling, } \\
\text { punctuation, and } \\
\text { capitalization. }\end{array}$ & $\begin{array}{l}6 \text { to } 10 \text { points } \\
\text { The student has } \\
\text { demonstrated limited } \\
\text { vocabulary or variety } \\
\text { of expression. The } \\
\text { student has an } \\
\text { average of } 3 \text { or } 4 \\
\text { errors per page in } \\
\text { grammar, syntax, } \\
\text { spelling, punctuation, } \\
\text { and capitalization. }\end{array}$ & $\begin{array}{l}0 \text { to } 5 \text { points } \\
\text { The student has utilized a } \\
\text { vocabulary with little or no } \\
\text { range and/or no variety in } \\
\text { expression. The student } \\
\text { has an average of more } \\
\text { than } 4 \text { errors per page in } \\
\text { grammar, syntax, spelling, } \\
\text { punctuation, and } \\
\text { capitalization. }\end{array}$ \\
\hline Form $\odot$ & $\begin{array}{l}16 \text { to } 20 \text { points } \\
\text { The report follows APA } \\
\text { format. The student has } \\
\text { organized ideas into } \\
\text { coherent paragraphs with } \\
\text { smooth transitions. The } \\
\text { assignment has good } \\
\text { structure and unity. }\end{array}$ & $\begin{array}{l}11 \text { to } 15 \text { points } \\
\text { The report follows APA format. } \\
\text { Transitions are sometimes } \\
\text { awkward, and/or the } \\
\text { assignment does not always } \\
\text { hold together. }\end{array}$ & $\begin{array}{l}6 \text { to } 10 \text { points } \\
\text { The report deviates } \\
\text { from APA format in a } \\
\text { number of areas. } \\
\text { There is weakness in } \\
\text { one of the following } \\
\text { criteria: organized } \\
\text { paragraphs or smooth } \\
\text { transitions. }\end{array}$ & $\begin{array}{l}\mathbf{0} \text { to } 5 \text { points } \\
\text { The report does not follow } \\
\text { APA format. The student } \\
\text { has not demonstrated an } \\
\text { understanding of } \\
\text { paragraph structure, } \\
\text { transitions, or unity. } \\
\text { Student has not adhered } \\
\text { to NU Masters Research } \\
\text { Project guidelines. }\end{array}$ \\
\hline
\end{tabular}

Figure 3: Grading Rubric for Project Report

\section{Students Feedback}

The Trifecta of Engagement framework was piloted in the online course ENM603 Operations Management in October 2017. The above mentioned class activities were successive applied and very well received by students. The students demonstrated an apparent increase in engagement, enthusiasm toward the subject matter and depth of learning through the threaded discussions, group project and weekly journal assignment etc. The rubrics not only made the evaluation and grading consistent, accurate and fair, but also as a formative tool help students develop understanding and skills, make dependent judgments about the quality of their own work. Selected students' comments were listed below:

"My engagement in the class was increased with the journal assignment and the group project." "I definitely had a lot of interactions and discussions with my team member when working on the group project."

"Professor provided timely feedback on my project through weekly project journal."

"I like the rubrics. They help us understand the expectations of the instructor, and provide us guidance when we write the journal and project report. "

The same course was also offered onsite face-to-face in September 2017 taught by the same 
instructor. Comparing to the online course, the onsite course has the same contents, homework assignments, quizzes, final exam and project, but without instructional videos , threaded discussions, journal assignment, and Blackboard collaborate sessions. The end of course students assessments on Student Perception of Learning were summarized and compared in Table 2 and Figure 4. Although lacks of the face-to-face communication, the online course with Trifecta of Engagement framework applied prevailed over the onsite course in all of the assessment questions.

Table 2: Student Perception of Learning

\begin{tabular}{|l|l|l|}
\hline \multicolumn{1}{|c|}{ Questions } & \multicolumn{1}{|c|}{$\begin{array}{c}\text { Online } \\
\text { (Mean) }\end{array}$} & \multicolumn{1}{|c|}{$\begin{array}{c}\text { Onsite } \\
\text { (Mean) }\end{array}$} \\
\hline My ability to write about this subject has improved. & 4.8 & 4.25 \\
\hline $\begin{array}{l}\text { The required speaking assignment(s) improved my oral } \\
\text { communication skills. }\end{array}$ & 4.8 & 4.25 \\
\hline I gained significant knowledge about this subject. & 4.6 & 4.5 \\
\hline My ability to think critically about topics in this class has improved. & 4.8 & 4.5 \\
\hline My ability to do research has improved. & 5 & 4.75 \\
\hline Discussions contributed to my learning. & 5 & 4.75 \\
\hline I can apply what I learned in this course beyond the classroom. & 4.25 & 4.25 \\
\hline I can apply what I learned in this course to my job or career goals. & 5 & 4.5 \\
\hline Student Perception of Learning Mean & $\mathbf{4 . 7 9}$ & $\mathbf{4 . 4 7}$ \\
\hline
\end{tabular}
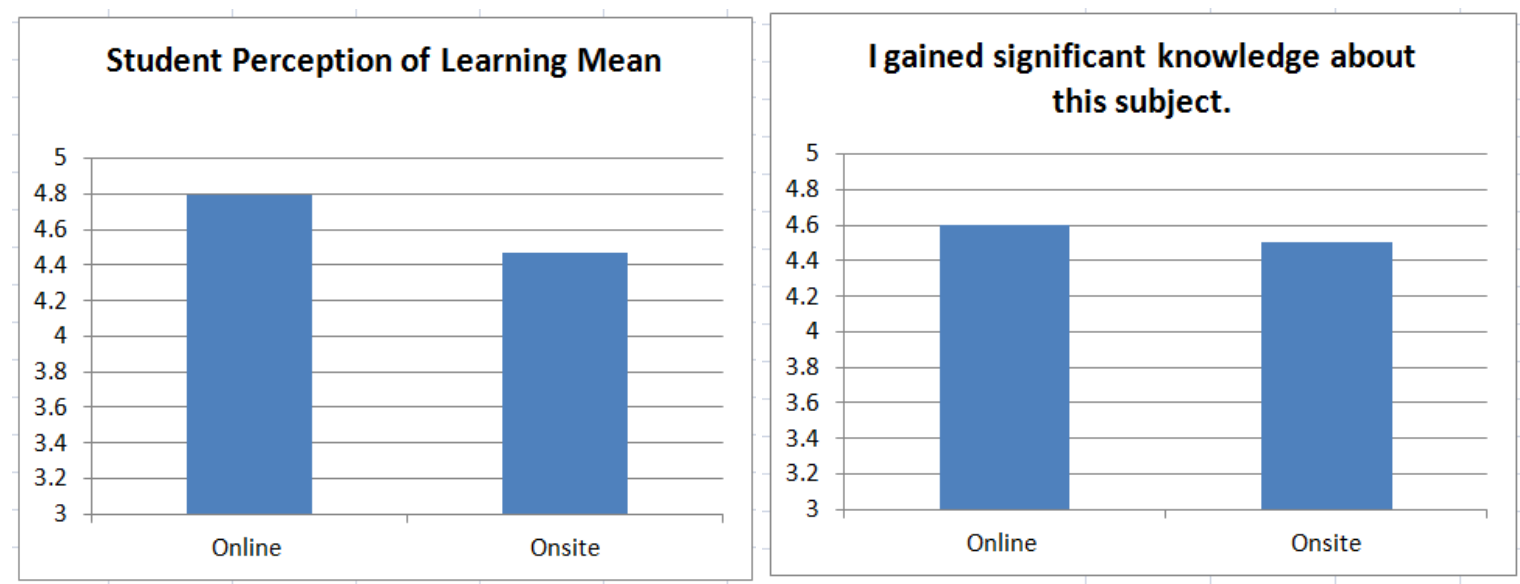

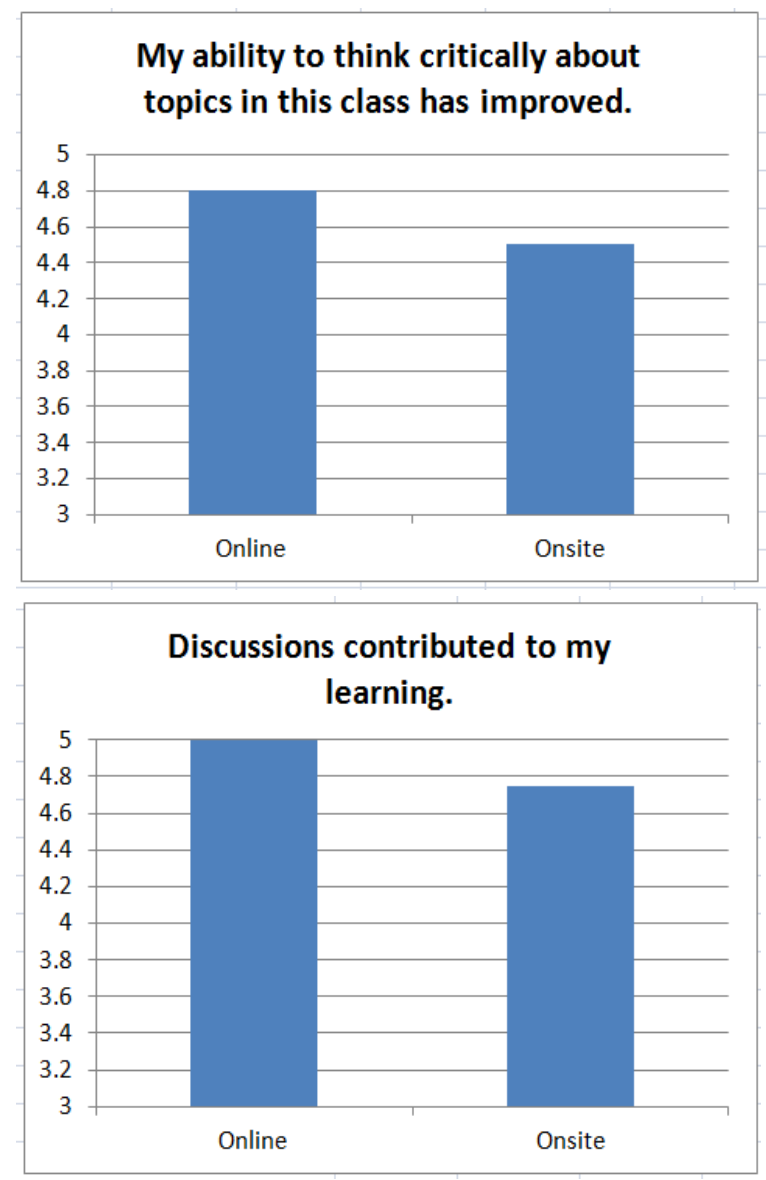

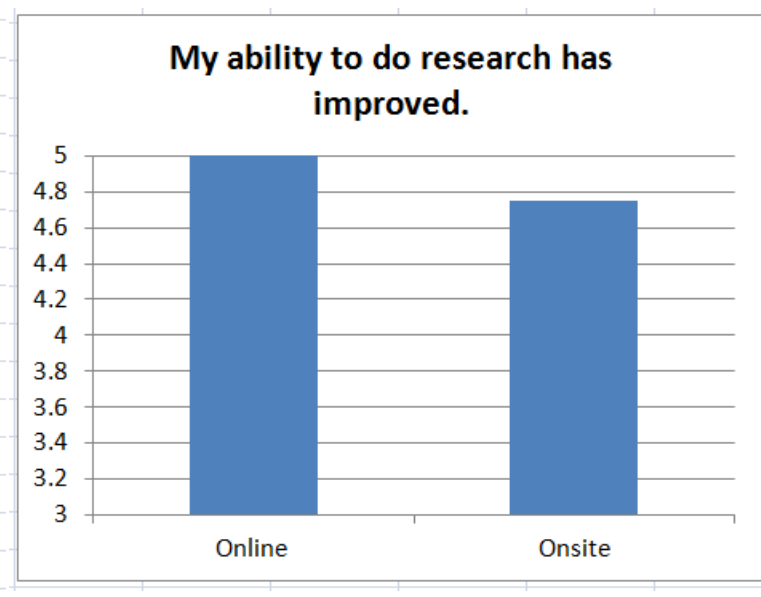

My ability to write about this subject has improved.

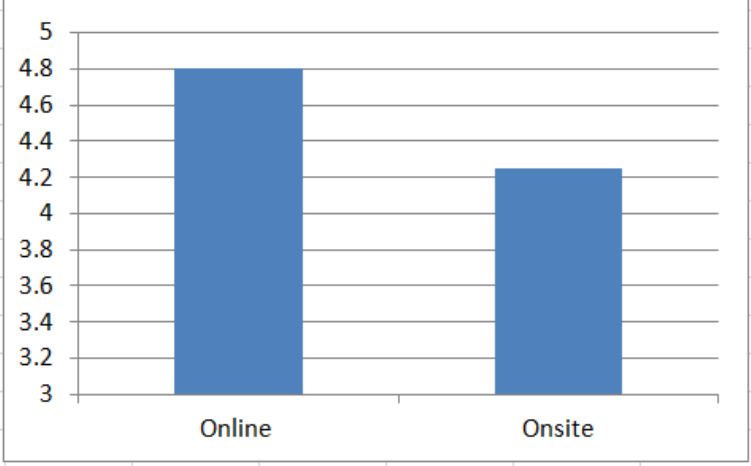

Figure 4: Student Assessment on Learning

The end-of-course survey reveals the Trifecta of Engagement framework greatly facilitated students' engagement with course contents, peers and instructor. Students took a more active part in their learning process. They gained significant knowledge about the subject and their ability to think critically, to do research, to write and speak has improved. The limited number of students participating in above mentioned online and onsite courses prohibited the collection of concrete quantitative results. However, this study's purpose and execution yielded significant results in terms of successful proof of concept and practices, which can act as a starting point for additional research.

\section{Conclusion}

Student engagement is the key to student's success in learning, especially for online courses in which the students and instructor are physically separated. To fully engage in a course, students not only need to engage with course contents, but also engage with peers and the instructor. The Trifecta of Engagement framework can be achieved through well-designed course contents and class activities. Evidence in the author's ENM603 online course shows that the engagement 
stimulates student's enthusiasm toward the subject matter, enhances student's learning ability and competency, and increases the depth of learning.

The Trifecta of Engagement framework will continue to be used in the future offerings of the Operations Management course and other online courses that the author is going to teach. As more students participate, more data will be collected and quantitative analysis will be conducted to show the effectiveness of the proposed methods.

\section{Bibliography}

[1] L. J. Krajewski, L.P. Ritzman and M.K. Malhotra, Operations management processes and supply chains, Prentice Hall, 2010.

[2] C.M. Christensen and P.R. Carlile, "Course research: using the case method to build and teach management theory", J. of Academy of Manage. Learning \& Educ., vol. 8, no. 2, pp. 240-251, 2009.

[3] L. Guo, "Teaching mode innovation for undergraduates in operations management", World Transactions on Engineering and Technology Education, vol. 12, no. 2, pp. 152-154, 2014.

[4] K. A. Meyer, "Face-to-face versus threaded discussions: the role of time and higher-order thinking", JALN, vol. 7-3, 2003.

[5] J. Paskey, "A survey compares 2 Canadian MBA programs, one online and one traditional", The Chronicle of Higher Education, April 26, 2001. [Online]. Available: http://chronicle.com/free/2001/04/2001042601u.html.

[6] D. R. Newman, B. Webb and C. A. Cochrane, "Content analysis method to measure critical thinking in faceto-face and computer supported group learning", 1999. Available: http://www.qub.ac.uk/mgt/papers/methods /contpap.html.

[7] R. M. Felder and R. Brent, "The ABC's of engineering education: ABET, Bloom's taxonomy, cooperative learning, and so on", Proceedings of the 2004 American Society for Engineering Education Annual Conference and Exposition, Portland, OR, July 27-30, 2004.

[8] J. Jaurez, P. Fu, R. Uhlig and S. Viswanathan, "Beyond simulation: student-built virtual reality games for cellular network design", Proceedings of the 2010 American Society for Engineering Education Annual Conference and Exposition, Louisville, KY, June 20-23, 2010.

[9] "Student Engagement", The Glossary of Education Reform for Journalists, Parents and Community Members, 02, 2016. Available: https://www.edglossary.org/student-engagement/.

[10] J. A. Fredricks, P. C. Blumenfeld and A. H. Paris, "School Engagement: Potential of the Concept, State of the Evidence", Review of Educational Research, vol. 74, no.1, pp.59-109, 2004.

[11] H. Coates, "A Model of Online and General Campus-Based Student Engagement", Assessment and Evaluation in Higher Education, vol. 32, no. 2, pp. 121-141, 2007.

[12] J. McDonald, S.C. Yanchar and R.T. Osguthorpe, "Learning from programmed instruction: Examining implications for modern instructional technology", Educational Technology Research \& Development, vol. 53, no. 2, pp. 84-98, 2005.

[13] B. Karge, "Effective strategies for engaging adult learners", Journal of College Teaching \& Learning, vol. 812, 2011.

[14] A. Hasan, "Effectiveness of teaching strategies for engaging adults who experienced childhood difficulties in learning mathematics", Learning Environ Res, vol. 18, pp. 1-13, 2015.

[15] H. Choi and S.D. Johnson, "The effect of context-based video instruction on learning and motivation in online courses", The American Journal of Distance Education, vol. 19-, no.4, pp. 215-227, 2005.

[16] N. Rutten, W.R. Van Joolingen, and J.T. Van Der Veen, "The learning effects of computer simulations in science education", Computers \& Education, vol. 58, pp. 136-153, 2012.

[17] A. Bandura, Social learning theory, Englewood Cliffs, NJ: Prentice-Hall, 1977.

[18] T. Roberts, Online collaborative learning: Theory and practice, Hershey, PA: Information Science Publishing, 
2004.

[19] L. Harasim, Learning theory and online technologies, New York: Routledge, 2012.

[20] V.P. Dennen, A.A. Darabi, and L.J. Smith, "Instructor-learner interaction in online courses: The relative perceived importance of particular instructor actions on performance and satisfaction", Distance Education, vol. 28, no. 1, pp. 65-79, 2007.

[21] M. D. Dixson, "Creating effective student engagement in online courses: What do students find engaging?", Journal of the Scholarship of Teaching and Learning, vol. 10, no. 2, pp. 1-13, 2010. 